\title{
Perinatal and Medical Risk Factors in Children with Attention Deficit Hyperactivity Disorder, Autism Spectrum Disorder or Specific Learning Disorder: Comparison Between Diagnostic Groups
}

\author{
Dikkat Eksikliği Hiperaktivite Bozukluğu, Otizm Spektrum Bozukluğu veya Özgül \\ Öğrenme Bozukluğu Olan Çocuklarda Perinatal ve Tıbbi Risk Faktörleri: Tanı Grupları \\ Arası Karşılaștırma
}

\author{
(1) Berkan Şahin ${ }^{1}$, (D) Abdullah Bozkurt2 (1) Koray Karabekiroğlu³ \\ ${ }^{1}$ Giresun University Faculty of Medicine, Department of Child and Adolescent Psychiatry, Giresun, Turkey \\ ${ }^{2}$ Konya Training and Research Hospital, Clinic of Child and Adolescent Psychiatry, Konya, Turkey \\ 30ndokuz Mayıs University Faculty of Medicine, Department of Child and Adolescent Psychiatry, Samsun, Turkey
}

\begin{abstract}
Introduction: Epigenetic changes in the pathogenesis of neurodevelopmental disorders, including prenatal and early life exposures, are becoming as appealing as hereditary genes. This study aimed to investigate possible pre-pubertal environmental and developmental risk factors for children with Attention Deficit Hyperactivity Disorder (ADHD), Autism Spectrum Disorder (ASD), and Specific Learning Disorder (SLD).

Methods: The study included 98 children (24 ADHD, 24 SLD, 26 ASD, 20 controls) aged 7-12 years. The diagnostic evaluation was based on the American Psychiatric Association Diagnostic and Statistical Manual of Mental Disorders and Schedule for Affective Disorders and Schizophrenia for School-age Childrenpresent version. Parents completed socio-demographic data form for clinical evaluation, and The Wechsler Children's Intelligence scale was used to assess cognitive skills.
\end{abstract}

Results: In our study, low parental education level, parental unemployment, low-income, and history of psychiatric disorders in first-degree relatives were associated with SLD risk, prematurity, and early self-regulation difficulties were associated with ASD risk, and history of allergy was associated with ADHD risk.

Conclusion: In this study, the presence of many different risk factors that play a possible role in neurodevelopmental disorders suggests that further epigenetic studies are needed.

Keywords: Specific Learning Disorder, autism spectrum disorder, attention deficit hyperactivity disorder, developmental characteristics, risk factors öz

Amaç: Nörogelişimsel bozuklukların patogenezinde doğum öncesi ve erken yaşam dönemi maruziyetlerini içeren epigenetik değişiklikler, kalıtsal genler kadar ilgi çekici olmaya bașlamaktadır. Bu çalıșmada puberte öncesi dönemde dikkat eksikliği hiperaktivite bozukluğu (DEHB), otizm spektrum bozukluğu (OSB) ve özgül öğrenme bozukluğu (ÖÖB) tanılı çocuklar için olası çevresel ve gelişimsel risk faktörlerinin araștırılması amaçlanmıștır.

Yöntemler: Çalıșmaya 7-12 yaș aralığında 98 çocuk (24 DEHB, 24 ÖÖB, 26 OSB, 24 kontrol) alınmıştır. Tanısal değerlendirmede Amerikan Psikiyatri Birliği Ruhsal Bozuklukların Tanısal ve Sayımsal El Kitabına dayalı görüşme, Okul Çağı Çocukları için Duygulanım Bozuklukları ve Şizofreni Görüșme Çizelgesi-șimdi versiyonu kullanılmıştır. Klinik değerlendirmede ebeveynler tarafından sosyo-demografik veri formu doldurulmuştur ve bilișsel değerlendirmede Wechsler Çocuklar Iç̧in Zeka ölçeği kullanılmıștır.

Bulgular: Çalışmamızda düşük ebeveyn eğitim düzeyi, ebeveyn işsizliği, düşük gelirli aile ve birinci derece akrabalarda psikiyatrik hastalık öyküsü ÖÖB riski ile, prematürite öyküsü ve erken dönem kendini düzenleme güçlükleri OSB riski ile, allerji öyküsü DEHB riski ile ilișkili bulunmuștur.

Sonuç: Bu çalıșmada nörogelişimsel bozukluklarda olası rol oynayan pek çok farklı risk faktörü bulunması ileri epigenetik çalışmalara ihtiyaç olduğunu göstermektedir.

Anahtar Kelimeler: Öğrenme bozukluğu, otizm spektrum bozukluğu, dikkat eksikliği hiperaktivite bozukluğu, gelişimsel özellikler, risk faktörleri
Address for Correspondence/Yazıșma Adresi: Berkan Șahin MD, Giresun University Faculty of Medicine, Department of Child and Adolescent Psychiatry, Giresun, Turkey

Phone: +90 5464823293 E-mail: mail.berkan@gmail.com ORCID ID: orcid.org/0000-0003-4699-3418

Cite this article as/Atıf: Șahin B, Bozkurt A, Karabekiroğlu K. Perinatal and Medical Risk Factors in Children with Attention Deficit Hyperactivity Disorder, Autism Spectrum Disorder or Specific Learning Disorder: Comparison Between Diagnostic Groups. İstanbul Med J 2019; 20(6): 502-7.

(c) Copyright 2019 by the Istanbul Training and Research Hospital/istanbul Medical Journal published by Galenos Publishing House.

(C) Telif Hakkı 2019 Istanbul Ĕgitim ve Araștırma Hastanesi/Istanbul Tıp Dergisi, Galenos Yayınevi tarafından basılmıștır.
Received/Geliș Tarihi: 16.11.2018 Accepted/Kabul Tarihi: 20.08.2019 
Şahin et al. Environmental Factors in Neurodevelopmental Disorders

\section{Introduction}

Attention Deficit Hyperactivity Disorder (ADHD), Autism Spectrum Disorder (ASD), and Specific Learning Disorder (SLD) are the most common neuropsychiatric disorders in childhood. These disorders are classified under the heading of Neurodevelopmental Disorders in the American Psychiatric Association's Diagnostic and Statistical Manual of Mental Disorders (DSM-5). Neurodevelopmental disorders occur early in development and are characterized by developmental disabilities that lead to disruptions in individual, social, educational, or occupational functionalities.

ADHD is a heterogeneous developmental disorder characterized by inattention, impulsivity, and hyperactivity. It is common among neurodevelopmental disorders, and the current diagnostic criteria are met in 5.3\% of school-aged children worldwide and $8 \%$ throughout Turkey (1,2). DSM-5 defined ASD as a neurodevelopmental disorder that starts in early childhood with impairment in social interaction, repetitive behaviors, and circumscribed interests. In a study report published by "US Centers for Disease Control and Prevention" in 2014 among children aged eight years, the prevalence of ASD was reported as 1/68 (3). There are few studies regarding the prevalence of autism in children in Turkey, and school-age autism prevalence has been reported to be approximately $12 / 10000$ (4). SLD is defined as a neurodevelopmental disorder that lasts for at least six months despite appropriate interventions, including difficulties in learning and using school skills. The difficulties these children experience are beyond the "expected situation" given their age and general cognitive skills, and it cannot be explained by delay in cognitive development in general. They may experience difficulties in academic, attention, organizing, ordering, and social-emotional fields (5). Its incidence has been reported to be 3-10\% among school-age children (6).

Neurodevelopmental disorders show a high level of heredity and have shared genetic risks. Epigenetic changes, including prenatal and early life exposures in the pathogenesis of neurodevelopmental disorders, are becoming as appealing as hereditary features (7). Many risk factors such as prenatal maternal stress, poor intrauterine environment, postpartum maternal depressive mood, short duration of breastfeeding, low birth weight, prematurity, and education of the mother have been defined for ADHD, ASD, or SLD (8-12). In the literature, it was seen that the risk factors and developmental characteristics of children with SLD were not examined sufficiently in our country.

Determination of risk factors for ADHD, ASD, and SLD, which are the most common neurodevelopmental disorders of childhood, is an essential objective for child mental health research and developmental psychology. We aimed to contribute to the literature by comparing these three diagnoses with similar phenomenological and etiological features in terms of socio-demographic and developmental/clinical features in a cohort from Turkey. In light of this information, this study aimed to investigate possible pre-pubertal risk factors for children with ADHD, SLD, and ASD.

\section{Methods}

\section{Participants}

Our study has a single-center, cross-sectional, case-control study design. The study cohort included 24 children (7-12 years) diagnosed as ADHD, 24 children (7-12 years) diagnosed as SLD, 26 children (7-12 years) diagnosed as ASD and 24 healthy controls (7-12 years) who applied to Ondokuz Mayıs University Faculty of Medicine Health Application and Research Center Child and Adolescent Psychiatry Outpatient Clinic. The diagnoses of the patient groups were made by clinical interviews based on DSM-5, and participants with a Wechsler Children's Intelligence Scale-R (WISC-R) score of less than 70 were excluded from the study. The standard exclusion criteria in patient groups were as follows: comorbid psychotic disorder, bipolar disorder, eating disorder, substance use disorder, neurological disease, or loss of consciousness for more than one hour due to trauma, unstable or chronic medical disease, and known visual and hearing deficits. Also, the presence of SLD or ASD findings in the ADHD group, the presence of ASD comorbidity in the SLD group, and the presence of SLD comorbidity in the ASD group were identified as exclusion criteria. The healthy control group was selected from children who had more than 70 points in WISC-R and who had no history of psychiatric or medical illness.

The study was approved by Ondokuz Mayıs University Clinical Research Ethics Committee (B.30.0DM.0.20.08/632-745 dated: 15.02.2017). Informed consent was obtained from the parents of the children.

\section{Application}

After the diagnostic evaluation of the case groups identified for our study, patients, healthy controls, and their families were informed about our research. Socio-demographic data form, which was used to reevaluate the inclusion and exclusion criteria of the study, was completed by researches following socio-demographic data, medical history, family history, prenatal, perinatal, and postnatal period information, developmental stages information obtained from the parents of the participants. The comorbidities were evaluated using Schedule for Affective Disorders and Schizophrenia for School-age Children-Present - Turkish Adaptation (SADS-P-T) $(13,14)$.

\section{Statistical Analysis}

Data were analyzed with IBM SPSS V23.0 (Chicago, USA). The normality of the data was examined by the Shapiro-Wilk test. One-way ANOVA was used to compare quantitative data with a normal distribution. KruskalWallis test was used to compare non-normally distributed data, and the source of the difference was examined by the Mann-Whitney $U$ test with Bonferroni correction. The correlation between categorical data was examined by chi-square test. The significance level was accepted as $p<0.05$.

\section{Results}

A total of 98 participants, including 24 children with SLD, 24 children with ADHD and 26 children with ASD according to DSM-5, and 24 healthy controls without any psychiatric diagnosis, completed the study. It was seen that $78.6 \%(n=77)$ of the children included in the study 
were male, and $21.4 \%(n=21)$ were female. The mean age and gender distributions were similar between the groups. There was a significant difference between the groups in terms of maternal $(p<0.001)$ and paternal education level $(p=0.001)$, maternal $(p<0.001)$ and paternal employment status $(p=0.006)$, monthly income $(p<0.001)$ and history of mental disorders in first-degree relatives $(p=0.007)$ (Table 1).

When the prenatal, perinatal and postnatal characteristics of the subjects included in the study were examined, the presence of a history of mental problems during pregnancy $(p=0.009)$, premature birth $(p=0.027)$ and allergy $(p=0.021)$ showed a significant difference between the groups (Table 2).

Significant differences were found between the groups in terms of firstword acquisition $(p=0.012)$, sentence generation $(p<0.001)$, and self-regulation as expressed by the mother $(p=0.013)$ (Table 3).
The children in the study group were evaluated with (SADS-P-T) during the study in terms of present mental disorders. There was no difference between the patient groups in terms of the presence of comorbid disorders (Table 4).

\section{Discussion}

Neurodevelopmental disorders are coexisting and persistent disorders in the development of cognitive or motor functions during childhood. In this study, the main clinical gain of focusing on neurodevelopmental disorders is to draw attention to early risk characteristics of mental disorders in childhood and early adolescence. The fact that neurodevelopmental disorders show similar male gender predominance and neurocognitive disorder suggests that there may be similar causal pathways leading to different disorders (15). Epigenetic

\section{Table 1. Socio-demographic characteristics of cases}

\begin{tabular}{|c|c|c|c|c|c|c|}
\hline & SLD & ADHD & ASD & Control & Test statistics & p \\
\hline Age & $9(7-12)$ & $9(7-12)$ & $9.5(7-12)$ & $10(7-12)$ & $\chi^{2}=5.753 * *$ & 0.124 \\
\hline \multicolumn{7}{|l|}{ Gender } \\
\hline Male & $16(66.7)$ & $18(75.0)$ & $23(88.5)$ & $20(83.3)$ & \multirow{2}{*}{$\chi^{2}=4.036^{*}$} & \multirow{2}{*}{0.258} \\
\hline Female & $8(33.3)$ & $6(25.0)$ & $3(11.5)$ & $4(16.7)$ & & \\
\hline Maternal education (years) & $5(0-16)^{a}$ & $11(0-16)^{a b}$ & $8(5-15)^{a b}$ & $13(5-20)^{b}$ & $x^{2}=18.853^{* *}$ & $<0.001$ \\
\hline Paternal education (years) & $5(3-12)^{a}$ & $11(1-16)^{a b}$ & $11(5-15)^{b}$ & $13(5-20)^{b}$ & $x^{2}=16.572 * *$ & 0.001 \\
\hline Maternal employment status, (working) n (\%) & $2(8.3)^{\mathrm{a}}$ & $9(37.5)^{b}$ & $7(26.9)^{\mathrm{ab}}$ & $17(70.8)^{c}$ & $x 2=21.638^{* *}$ & $<0.001$ \\
\hline Paternal employment status, (working) n (\%) & $19(79.2)^{a}$ & $23(95.8)^{\mathrm{ab}}$ & $26(100.0)^{b}$ & $24(100.0)^{b}$ & $\chi^{2}=12.457^{*}$ & 0.006 \\
\hline F-M status (together), n (\%) & $22(91.7)$ & $23(95.8)$ & $25(96.2)$ & $23(95.8)$ & $\chi^{2}=0.689 *$ & 0.876 \\
\hline Consanguinity between parents (yes) $n$ (\%) & $2(8.3)$ & $2(8.3)$ & $7(26.9)$ & $2(8.3)$ & $\chi^{2}=5.737^{*}$ & 0.125 \\
\hline \multicolumn{7}{|l|}{ Monthly income (TL) } \\
\hline$<1300$ & $8(33.3)$ & $3(12.5)$ & $2(7.7)$ & $0(0.0)$ & \multirow{3}{*}{$\chi 2=25.374^{*}$} & \multirow{3}{*}{$<0.001$} \\
\hline $1300-4500$ & $15(62.5)$ & $19(79.2)$ & $21(80.8)$ & $14(58.3)$ & & \\
\hline$>4500$ & $1(4.2)$ & $2(8.3)$ & $3(11.5)$ & $10(41.7)$ & & \\
\hline Mental disorders in first degree relatives (yes) $n$ (\%) & $13(54.2)^{\mathrm{a}}$ & $9(37.5)^{\mathrm{ab}}$ & $5(19.2)^{\mathrm{ab}}$ & $3(12.5)^{b}$ & $\chi^{2}=12.097^{*}$ & 0.007 \\
\hline
\end{tabular}

Table 2. Evaluation of prenatal, perinatal and postnatal characteristics of cases

\begin{tabular}{|c|c|c|c|c|c|c|}
\hline & SLD & ADHD & ASD & Control & Test statistics & $p$ \\
\hline Maternal age & $29(17-39)$ & $27(18-38)$ & $24(19-35)$ & $32(18-41)$ & $x^{2}=8.2$ & 0.050 \\
\hline Smoking during pregnancy n (\%) & $4(16.7)$ & $4(16.7)$ & $2(7.7)$ & $1(4.2)$ & $x^{2}=2.952$ & 0.399 \\
\hline Mental problems in pregnancy n (\%) & $14(58.3)^{\mathrm{a}}$ & $14(58.3)^{a}$ & $10(38.5)^{\mathrm{ab}}$ & $4(16.7)^{b}$ & $x^{2}=11.622$ & 0.009 \\
\hline \multicolumn{7}{|l|}{ Delivery method } \\
\hline NSVD & $8(33.3)$ & $9(37.5)$ & 10 (38.5) & 8 (33.3) & \multirow{3}{*}{$\chi 2=3.428$} & \multirow{3}{*}{0.753} \\
\hline $\mathrm{C} / \mathrm{S}$ & $16(66.7)$ & $14(58.3)$ & $16(61.5)$ & $16(66.7)$ & & \\
\hline Forceps & $0(0)$ & $1(4.2)$ & $0(0)$ & $0(0)$ & & \\
\hline Prematurity & $2(8.3)^{a b}$ & $1(4.2)^{\mathrm{ab}}$ & $7(26.9)^{b}$ & $0(0)^{\mathrm{a}}$ & $\chi 2=14.255$ & 0.027 \\
\hline Birth complication n (\%) & $2(8.3)$ & $3(12.5)$ & $3(11.5)$ & $2(8.3)$ & $\chi 2=0.372$ & 0.946 \\
\hline Asphyxia n (\%) & $3(12.5)$ & $2(8.3)$ & $1(3.8)$ & $2(8.3)$ & $\chi^{2}=1.25$ & 0.741 \\
\hline Incubator n (\%) & $2(8.3)$ & $5(20.8)$ & $4(15.4)$ & $0(0)$ & $\chi 2=5.911$ & 0.116 \\
\hline Seizure n (\%) & $1(4.2)$ & $4(16.7)$ & $1(3.8)$ & $1(4.2)$ & $\chi 2=4.349$ & 0.226 \\
\hline Allergy n (\%) & $2(8.3)^{a}$ & $10(41.7)^{b}$ & $5(19.2)^{a}$ & $3(12.5)^{a}$ & $\chi 2=9.778$ & 0.021 \\
\hline
\end{tabular}

SLD: specific learning disorder, ADHD: attention deficit hyperactivity disorder, ASD: autism spectrum disorder, $\chi 2$ : pearson chi-square test statistic, a-b: there is no difference between groups with the same letter 
mechanisms, as well as high inheritance, can help explain how the same risk factors lead to different clinical characteristics. In this study, environmental factors, developmental and clinical features of children with neurodevelopmental disorders were determined. In the literature, when the etiological factors causing intellectual disability are examined, it is reported that approximately $30 \%$ are genetically based (16). In our study, children with normal intelligence performance were included in the study, considering that it would contribute to the evaluation of environmental and developmental risk factors as independent risk factors.

When the education levels of the parents were examined, it was seen that the parents of children with SLD had a lower educational level than the other parents. The mothers of all three patient groups are significantly less unemployed than the control group. The fathers of children with SLD had a significant unemployment rate. When the monthly income reflecting the socio-economic level was examined, the groups with the lowest monthly income were children with SLD and ADHD, respectively. The results of both the family structure and the socio-demographic characteristics of the parents cannot exclude the effect of lack of interest and enviromental stimulus. However, the importance of socio-demographic factors in children with SLD is emphasized in the literature. Low levels of parental education and low socio-economic status were thought to be risk factors for academic difficulties. The low socio-economic status may indicate parental educational difficulties and possible learning disability in the parents as well as a risk factor involving specific environmental conditions (17). Meta-analysis studies show that the socio-economic structure of parents has a substantial impact on students' academic achievement. The support systems provided at home provide the basis for the academic success of the students. It has been found that schools with higher socioeconomic status have many significant advantages, such as teaching arrangements, materials, teacher experience, and teacher-student ratio (18). The presence of many confounding factors makes it difficult to establish a causal relationship between socio-economic status and academic achievement. However, advanced parental education levels may indicate that children with SLD can receive effective education in

Table 3. Evaluation of developmental stages of cases

\begin{tabular}{|c|c|c|c|c|c|c|}
\hline & SLD & ADHD & ASD & Control & Test Statistics & p \\
\hline Word (months) & $12(9-36)^{b}$ & $12(7-48)^{b}$ & $21(7-48)^{a}$ & $12(9-24)^{b}$ & $\chi^{2}=10.9$ & 0.012 \\
\hline Sentence (months) & $24(12-36)^{b}$ & $24(12-60)^{b}$ & $36(15-60)^{a}$ & $18(11-48)^{b}$ & $\chi^{2}=23.9$ & $<0.001$ \\
\hline Walking (months) & $16(9-36)$ & $12(8-30)$ & $12(10-24)$ & $12(9-18)$ & $\chi^{2}=7.9$ & 0.050 \\
\hline Toilet (months) & $36(18-72)$ & $36(24-54)$ & $36(1-60)$ & $27(20-36)$ & $x^{2}=7.4$ & 0.061 \\
\hline Breasting feeding (months) & $10.5(0-42)$ & $21(0-42)$ & $10.5(2-36)$ & $18(5-27)$ & $x^{2}=2.7$ & 0.448 \\
\hline \multicolumn{7}{|l|}{ Self-regulation } \\
\hline Difficult & $9(37.5)^{a}$ & $7(29.2)^{a}$ & $14(56)^{b}$ & $3(12.5)^{a}$ & \multirow{2}{*}{$x^{2}=10.714$} & \multirow{2}{*}{0.013} \\
\hline Easy & $15(62.5)$ & $17(70.8)$ & $11(44)$ & $21(87.5)$ & & \\
\hline
\end{tabular}

SLD: specific learning disorder, ADHD: attention deficit hyperactivity disorder, ASD: autism spectrum disorder, a-b: there is no difference between groups with the same letter, $\chi 2$ : KruskalWallis test statistic

Table 4. Distributions of cases according to current mental disorders determined by SADS-P-T

\begin{tabular}{|c|c|c|c|c|c|c|}
\hline & \multicolumn{2}{|l|}{ SLD } & \multicolumn{2}{|c|}{ ADHD } & \multicolumn{2}{|c|}{ ASD } \\
\hline & $\mathrm{n}$ & $\%$ & $\mathrm{n}$ & $\%$ & $\mathrm{n}$ & $\%$ \\
\hline ADHD & 15 & 62.5 & 0 & 0 & 21 & 80.8 \\
\hline GAD & 7 & 29.2 & 4 & 16.7 & 1 & 3.8 \\
\hline SAD & 5 & 20.8 & 2 & 8.3 & 2 & 7.7 \\
\hline $\mathrm{OCD}$ & 2 & 8.3 & 0 & 0 & 4 & 15.4 \\
\hline Primary Enuresis & 3 & 12.5 & 4 & 16.7 & 0 & 0 \\
\hline Primary Encopresis & 2 & 8.3 & 1 & 4.2 & 0 & 0 \\
\hline ODD & 14 & 58.3 & 17 & 70.8 & 2 & 7.7 \\
\hline Behavioral Disorder & 5 & 20.8 & 2 & 8.3 & 1 & 3.8 \\
\hline Social Phobia & 2 & 8.3 & 2 & 8.3 & 6 & 23.1 \\
\hline Tic disorder & 1 & 4.2 & 1 & 4.2 & 0 & 0 \\
\hline Secondary Enuresis & 0 & 0.0 & 0 & 0.0 & 1 & 3.8 \\
\hline Secondary Encopresis & 0 & 0.0 & 0 & 0.0 & 1 & 3.8 \\
\hline Specific Phobia & 11 & 45.8 & 7 & 29.2 & 9 & 34.6 \\
\hline Major depression & 4 & 16.7 & 0 & 0.0 & 0 & 0 \\
\hline Comorbid disorder (yes) & 22 & 91.7 & 19 & 79.2 & 24 & 92.3 \\
\hline
\end{tabular}

$\chi 2=2.505, p=0.286$. SLD: Specific Learning Disorder, ADHD: attention deficit hyperactivity disorder, ASD: autism spectrum disorder, GAD: generalized anxiety disorder; SAD: separation anxiety disorder, OCD: obsessive-compulsive disorder, ODD: oppositional defiant disorder, $\chi 2$ : pearson chi-square test statistic 
intervention and management processes. As a result, low education status and unemployment of parents can be considered as an environmental and/or genetic risk factor for SLD in their children. There is a need for family-based studies in this area.

When the mental illnesses of the first-degree relatives of the cases were examined, it was seen that children with the neurodevelopmental disorder had higher rates than the control group. This rate, which reaches a significant level in children with SLD, is consistent with the relevant literature findings of neurodevelopmental disorders with a high level of heredity and shared genetic risk (19).

Prenatal, perinatal, and postnatal period data of the cases were examined. Psychological problems during pregnancy were significantly higher in the patient group. In the studies conducted, it is emphasized that exposure to perinatal stress may be one of the critical and practical epigenetic factors in neurodevelopmental diseases, particularly in the pathogenesis of ADHD and ASD $(20,21)$. It has been reported that physical and mental stress experienced during pregnancy may play a role in the etiology by causing changes through hypothalamic-pituitary-adrenal axis feedback mechanisms in children (22). When the birth weeks were examined, a significant prematurity history was found in the ASD group. It has been reported that the prevalence of prematurity is increased, especially in ADHD and ASD diagnostic groups and that there may be an increased risk between prematurity and these diseases $(23,24)$. Our study supports that prematurity is a risk factor for ASD diagnosis. Allergy history was significantly higher in the ADHD group compared to the other patient groups and control group. In the literature, allergy skin test positivity was found to be high in ADHD patients, and in community-based studies, it was shown that there was a significant relationship between ADHD and allergic/autoimmune diseases $(25,26)$. It has been reported that genes related to the immune system may be associated with ADHD, and hypersensitivity to environmental factors such as foods may contribute to the development of ADHD (27). Our results indicate that allergy history may be a risk factor in the ADHD group of neurodevelopmental disorders.

There was no significant difference between the groups in terms of smoking during pregnancy, mode of delivery, intra-partum complications, asphyxia, incubation, and seizure history. The smallness of our sample group may not have made a significant difference between the groups. In the literature, conflicting results can be seen in studies examining risk factors and perinatal conditions exposed during pregnancy. These results may arise from the methodological differences of the studies (28).

When the developmental stages of the cases were examined, it was seen that ASD patients with normal intelligence levels reached the developmental stage of saying at least two meaningful words and generate a sentence with at least two words at a later age. Delay in language development was not a significant clinical feature for ADHD and SLD. One of the essential features of infancy and early childhood is self-regulation. This skill has biological basics and is influenced by maturation and experience. Self-regulation is regulating the motor activity, affect, and increased and decreased endocrine and autonomic responses. It includes attachment-detachment, attention, behavioral inhibition, and self-appeasement (29). When the infancy and early childhood periods of participants were examined, it was seen that children with ASD had significant difficulty in developing these skills, and they were defined as "difficult babies" by their mothers.

The diagnostic groups were evaluated for the present psychiatric disorders with SADS-P-T. The most common associations in the diagnosis groups were ADHD and oppositional defiant disorder (ODD) in the SLD group, ODD and Specific Phobia in the ADHD group, and ADHD and Specific Phobia in the ASD group. The incidence rates of comorbid disorders were consistent with the literature $(30,31)$. It was found that $92 \%$ of the SLD group, $79 \%$ of the ADHD group, and $92 \%$ of the ASD group had at least one comorbid psychiatric diagnosis. It was found that the high incidence rate in the SLD and ASD groups was highly dependent on the comorbidity of ADHD.

\section{Study Limitations}

In our study, although there was no age and gender difference between the groups, equal gender recruitment within the groups could make the groups more homogeneous. The comorbid diagnosis of the patient groups may have impaired the homogeneity of the groups. Taking larger samples by checking all the comorbidities will strengthen the study data. Information from families may be considered as a limitation as it may show recall bias.

\section{Conclusion}

Regarding the independent risk factors investigated in this study, parental education level, parental employment status, monthly income of the family and psychiatric disease history in first degree relatives were related to SLD risk, history of prematurity and early self-regulation difficulties were related to ASD risk, and allergy history was related to ADHD risk. No significant single risk factor for all groups was identified. This suggests that further studies are needed to learn about the many different risk factors that contribute to neurodevelopmental disorders and to show how they can potentially interact.

Ethics Committee Approval: The study was approved by Ondokuz Mayıs University Clinical Research Ethics Committee (B.30.0DM.0.20.08/632745 date: 15.02 .2017$)$.

Informed Consent: Informed consent was obtained from the parents of the children.

Peer-review: Externally peer-reviewed.

Author Contributions: Concept - B.Ş., A.B., K.K.; Design - B.Ş., A.B., K.K.; Supervision - B.S., A.B., K.K.; Resources - B.S.; Data Collection and/or Processing - B.S.; Analysis and/or Interpretation - B.S., A.B.; Literature Search - B.S.; Writing Manuscript - B.S.; Critical Review - K.K.

Conflict of Interest: No conflict of interest was declared by the authors.

Financial Disclosure: The authors declared that this study received no financial support.

\section{References}

1. Polanczyk G, De Lima MS, Horta BL, Biederman J, Rohde LA. The worldwide prevalence of ADHD: a systematic review and metaregression analysis. Am J Psychiatry 2007; 164: 942-8. 
2. Zorlu A, Unlu G, Cakaloz B, Zencir M, Buber A, Isildar Y. The prevalence and comorbidity rates of ADHD among school-age children in Turkey. J Atten Disord 2015: 1087054715577991.

3. Baio J, Wiggins L, Christensen DL, Maenner MJ, Daniels J, Warren Z, et al. Prevalence of autism spectrum disorder among children aged 8 years-autism and developmental disabilities monitoring Network, 11 Sites, United States, 2014. MMWR Surveill Summ 2018; 67: 1-23.

4. Namal N, Vehit HE, Koksal S. Do autistic children have higher levels of caries? A cross-sectional study in Turkish children. J Indian Soc Pedod Prev Dent 2007; 25: 97 .

5. Snowling MJ. Specific learning difficulties. Psychiatry 2005; 4: 110-3.

6. Rutter M, Maughan B. Dyslexia: 1965-2005. Behav Cogn Psychother 2005; 33: 389-402.

7. Relton CL, Smith GD. Epigenetic epidemiology of common complex disease: prospects for prediction, prevention, and treatment. PLoS Med 2010; 7 : e1000356.

8. Schendel D, Bhasin TK. Birth weight and gestational age characteristics of children with autism, including a comparison with other developmental disabilities. Pediatrics 2008; 121: 1155-64.

9. Say GN, Karabekiroğlu K, Babadağı Z, Yüce M. Maternal stress and perinatal features in autism and attention deficit/hyperactivity disorder. Pediatr Int 2016; 58: 265-9.

10. Langridge AT, Glasson EJ, Nassar N, Jacoby P, Pennell C, Hagan R, et al. Maternal conditions and perinatal characteristics associated with autism spectrum disorder and intellectual disability. PLoS Med 2013; 8: e50963.

11. Ronald A, Pennell CE, Whitehouse AJ. Prenatal maternal stress associated with ADHD and autistic traits in early childhood. Front Psychol 2011; 1: 223.

12. Sun Z, Zou L, Zhang J, Mo S, Shao S, Zhong R, et al. Prevalence and associated risk factors of dyslexic children in a middle-sized city of China: a crosssectional study. PLoS Med 2013; 8: 56688.

13. Kaufman J, Birmaher B, Brent D, Rao U, Flynn C, Moreci P, et al. Schedule for affective disorders and schizophrenia for school-age children-present and lifetime version (K-SADS-PL): initial reliability and validity data. J Am Acad Child Adolesc Psychiatry 1997; 36: 980-8.

14. Gökler B, Ünal F, Pehlivantürk B, Kültür EC,, Akdemir D, Taner Y. Okul çăgi çocuklari için duygulanim bozukluklari ve şizofreni görüșme çizelgesi-şimdi ve yașam boyu șekli-türkçe uyarlamasinin geçerlik ve güvenirliği. Çocuk ve gençlik ruh sağliği dergisi 2004; 11: 109-16.

15. Thapar A, Pine DS, Scott S, Snowling MJ, Taylor EA. Rutter's child and adolescent psychiatry: John Wiley \& Sons; 2017. 38 p.

16. Rodríguez-Revenga LB, Madrigal-Bajo I, Mila-Racasens M. Genetic mental retardation. Rev Neurol 2006; 43: S181-6.
17. St. Sauver JL, Katusic SK, Barbaresi WJ, Colligan RC, Jacobsen SJ. Boy/girl differences in risk for reading disability: potential clues? Am J Epidemiol 2001 154: 787-94.

18. Sirin SR. Socio-economic status and academic achievement: A meta-analytic review of research. Rev Educ Res 2005: 75: 417-53.

19. Barkley RA. Hyperactive and normal girls and boys: Mother-child interaction, parent psychiatric status and child psychopathology. J Child Psychol Psychiatry 1985; 26: 439-52.

20. Gardener H, Spiegelman D, Buka SL. Prenatal risk factors for autism: comprehensive meta-analysis. Br J Psychiatry. 2009; 195: 7-14.

21. Froehlich TE, Anixt JS, Loe IM, Chirdkiatgumchai V, Kuan L, Gilman RC. Update on environmental risk factors for attention-deficit/hyperactivity disorder. Curr Psychiatry Rep 2011; 13: 333.

22. Viltart O, Mairesse J, Darnaudéry M, Louvart H, Vanbesien-Mailliot C, Catalani A, et al. Prenatal stress alters Fos protein expression in hippocampus and locus coeruleus stress-related brain structures. Psychoneuroendocrinology 2006; 31: 769-80.

23. Kuzniewicz MW, Wi S, Qian Y, Walsh EM, Armstrong MA, Croen LA. Prevalence and neonatal factors associated with autism spectrum disorders in preterm infants. J Pediatr 2014; 164: 20-5.

24. Lindström K, Lindblad F, Hjern A. Preterm birth and attention-deficit/ hyperactivity disorder in schoolchildren. Pediatrics 2011; 127: 858-65.

25. Chen MH, Su TP, Chen YS, Hsu JW, Huang KL, Chang WH, et al. Comorbidity of allergic and autoimmune diseases among patients with ADHD: a nationwide population-based study. J Atten Disord 2017; 21: 219-27.

26. Suwan P, Akaramethathip D, Noipayak P. Association between allergic sensitization and attention deficit hyperactivity disorder (ADHD). Asian Pac J Allergy Immunol 2011; 29: 57.

27. Pelsser LM, Buitelaar JK, Savelkoul HF. ADHD as a (non) allergic hypersensitivity disorder: a hypothesis. Pediatr Allergy Immunol 2009; 20: 107-12.

28. Kinney DK, Barch DH, Chayka B, Napoleon S, Munir KM. Environmental risk factors for autism: do they help cause de novo genetic mutations that contribute to the disorder? Med Hypotheses 2010; 74: 102-6.

29. Sarı BA. Mizaç özellikleri ve gelişime etkileri. Turkiye Klinikleri J PsychiatrySpecial Topics 2018; 4: 5-9.

30. Biederman J, Faraone SV, Taylor A, Sienna M, Williamson S, Fine C. Diagnostic continuity between child and adolescent ADHD: findings from a longitudinal clinical sample. J Am Acad Child Adolesc Psychiatry 1998; 37: 305-13.

31. Mattila M-L, Hurtig T, Haapsamo H, Jussila K, Kuusikko-Gauffin S, Kielinen $\mathrm{M}$, et al. Comorbid psychiatric disorders associated with Asperger syndrome/ high-functioning autism: A community-and clinic-based study. J Autism Dev Disord 2010; 40: 1080-93. 